\title{
EMPLOYEE PERFORMANCE EVALUATION USING ANALYTIC HIERARCHY PROCESS (AHP) FOR CHEMVI LABORATORY SDN. BHD.
}

\begin{abstract}
As market becomes more competitive, the management of human capital or retaining high performance employees becomes a major challenge for many organisations. In this regards, evaluation of employee performance is an important activity of human resource managers. The present paper applies AHP to evaluate performance of employees working in Chemvi Laboratory Sdn Bhd, a private Malaysian company. Criteria and subcriteria for the performance evaluation were obtained through group discussion with senior manager of the company Bhd. In fact, five senior managers were interviewed using AHP questionnaires and weight for criteria and subcriteria were evaluated using AHP Calc version 24.12.13 by Klaus D. Goepel. Overall, he management and employees are upbeat with the results obtained via AHP as the criteria and their meanings were clearly defined and communicated to the employees. Employees who performed poorly were also identified and recommendations were made on which criteria that they scored lower and how to improve their performance on those.
\end{abstract}

Keywords: Employee Performance Evaluation, AHP

\section{Introduction}

Lansburry (1988) defined employees performance evaluation as "the process of identifying, evaluating, and developing the work performance of the employee in the organization, so that organizational goal and objectives are effectively achieved while, at the same time, benefiting employees in term of recognition, receiving feedback and offering career guidance" Unfortunately, performance appraisals are not on the top of the list of "favorite things to do" for either managers or employees, and there can be a number of problems with their administration. From managers not being trained to conduct performance appraisals effectively to the failure to tie performance appraisal expectations to desired business results, businesses are often challenged to use this performance appraisal tool effectively.

\section{Literature Review}

Performance appraisal is one of the cornerstones of management control systems. Bruce 2013 stressed that appraisals can serve both administrative purposes (e.g., assigning tasks, distributing rewards, and making promotions) and developmental purposes (e.g., identifying employee strengths and weaknesses and assessing training needs).

International Symposium on the

1

London, U.K. Analytic Hierarchy Process 
Performance appraisal has been the subject of considerable research, literature reviews highlight the scarcity of studies on the performance appraisal practices. Accounting and economics researchers have primarily focused on the factors influencing the choice of performance measures (e.g., financial vs. nonfinancial, objective vs. subjective) for performance evaluation or compensation purposes (Bol, 2008), The organizational psychology literature has emphasized the psychometric properties of appraisal instruments and the effects of supervisor-subordinate interactions on performance appraisals (Levy and Williams 2004). Individuals' appraisal plan characteristics are likely to be influenced both by the organizational context of the firm and by the employees'specific employment characteristics. Moreover, the higher-level organizational factors (e.g., organizational structure) may moderate the relations between an individual employee's attributes (e.g., position in the hierarchy) and appraisal plan characteristics (Denisi, 2000).

\section{Hypotheses/Objectives}

The objectives of the present research are the following:

- Establish relevant set of criteria and subcriteria for performance appraisal for Chemvi Laboratory Sdn Bhd

- Determine the criteria and subcriteria weightage by interviewing key senior managers using Analytic Hierarchy Process (AHP) questionnaires.

- Evaluation of employees performance using the absolute measurement method of Analytic Hierarchy Process (AHP) and ranking of employees in the organization.

\section{Research Design/Methodology}

The criteria were determined in consultation of the senior managers and communicated with employees for their knowledge. Twenty employees were evaluated on the basis of those criteria and immediate supervisor evaluated them. The ranking of the employees in terms of their performance was made by absolute measurement of AHP.

\section{Data/Model Analysis}

The following table provides the criteria and subcriteria weights. 
ISAHP Article: A Style Guide for Paper Proposals To Be Submitted to the International Symposium on the Analytic Hierarchy Process 2016, London, U.K.

\begin{tabular}{|c|c|c|c|c|c|c|c|c|}
\hline Criteria & Weight & Rank & Subcriteria & & Weight & Overall Weight & $\%$ & Rank \\
\hline \multirow{3}{*}{ Services } & \multirow{3}{*}{0.221} & \multirow{3}{*}{2} & $\begin{array}{l}\text { Work } \\
\text { Completion }\end{array}$ & $\mathrm{C}_{11}$ & 0.304 & 0.067 & 6.72 & 8 \\
\hline & & & Commitment & $\mathrm{C}_{12}$ & 0.434 & 0.096 & 9.59 & 4 \\
\hline & & & Multitasking & $\mathrm{C}_{13}$ & 0.262 & 0.058 & 5.79 & 11 \\
\hline \multirow[b]{2}{*}{ Quality } & \multirow[b]{2}{*}{0.206} & \multirow[b]{2}{*}{3} & Skills & $\mathrm{C}_{21}$ & 0.679 & 0.140 & 13.98 & 2 \\
\hline & & & $\begin{array}{l}\text { Compliance } \\
\text { to ISO } 17025\end{array}$ & $\mathrm{C}_{22}$ & 0.321 & 0.066 & 6.62 & 9 \\
\hline \multirow{2}{*}{ Financial } & \multirow{2}{*}{0.140} & \multirow{2}{*}{5} & Budget & $\mathrm{C}_{31}$ & 0.498 & 0.070 & 6.97 & 7 \\
\hline & & & Sales Target & $\mathrm{C}_{32}$ & 0.502 & 0.070 & 7.03 & 6 \\
\hline \multirow{2}{*}{ Timing } & \multirow{2}{*}{0.160} & \multirow{2}{*}{4} & Punctuality & $\mathrm{C}_{41}$ & 0.629 & 0.101 & 10.06 & 3 \\
\hline & & & Attendance & $\mathrm{C}_{42}$ & 0.371 & 0.059 & 5.94 & 10 \\
\hline \multirow{3}{*}{$\begin{array}{l}\text { Teamwork/ } \\
\text { Cooperation }\end{array}$} & \multirow{3}{*}{0.273} & \multirow{3}{*}{1} & $\begin{array}{l}\text { Training \& } \\
\text { Development }\end{array}$ & $\mathrm{C}_{51}$ & 0.307 & 0.084 & 8.38 & 5 \\
\hline & & & Leisure & $\mathrm{C}_{52}$ & 0.135 & 0.037 & 3.69 & 12 \\
\hline & & & $\begin{array}{l}\text { Harmonious } \\
\text { work }\end{array}$ & $\mathrm{C}_{53}$ & 0.558 & 0.152 & 15.23 & 1 \\
\hline Total & 1.000 & & & & 5.000 & 1.000 & 100 & \\
\hline
\end{tabular}

Due to space limitation, all other details including the employee performance ranking were omitted

\section{Conclusions}

Employee performance evaluation system is very crucial in every organization. The outcome of performance evaluation is often used for year-end bonus rewards, salary increments, compensation, training need analysis and promotion of employees. Therefore, a very transparent and systematic performance evaluation system is deemed necessary for any organization. The present work has shown how AHP can be applied to conduct a fair performance evaluation exercise.

\section{Key References}

List here only those 3 to 5 references that are key for the study at hand. As an example:

Bol, J. (2008), Subjectivity in Compensation Contracts. Journal of Accounting Literature 27: 1-32. 
ISAHP Article: A Style Guide for Paper Proposals To Be Submitted to the International Symposium on the Analytic Hierarchy Process 2016, London, U.K.

Bruce, S. (2013). Performance Management Survey Results In; How Do You Compare?. HR Daily Advisor, June 13.

Denisi, A.S. (2000). Performance Appraisal and Performance Management: A Multilevel Analysis. In K.J. Klein and S. Kozlowski (Eds), Multilevel Theory, Research and Methods in Organizations. San Francisco: Jossey-Bass: 121-156.

Lansbury, R. (1988). Performance management: A process approach. Human Resource Management, Australia, 46-55.

Levy, P. E., \& William, J. R. (2004). The Social Context of Performance Appraisal. Journal of Management 30 (2004): 881-905. 